ENVIRONMENTAL

RESTORATION

PROGRAM

\title{
Completion Report for the Isolation and Remediation of Inactive Liquid Low-Level Radioactive Waste Tanks 7562, H-209, and T-30 at Oak Ridge National Laboratory, Oak Ridge, Tennessee
}

\section{REGEIVED \\ JAN 281997 \\ OSTI}

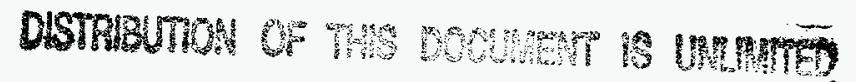

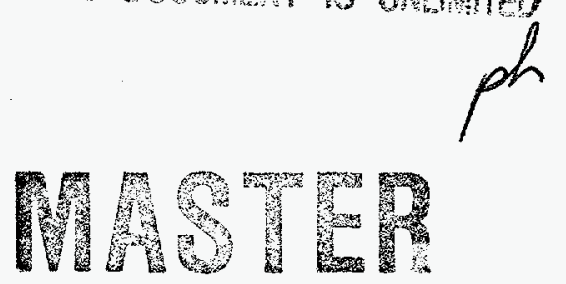

This document has been approved by the ORNL Technical Information Office for release to the public. Date: $12 / 27 / 96$

ENERGY SYSTEMS 


\section{DISCLAIMER}

Portions of this document may be illegible in electronic image products. Images are produced from the best available original document. 


\section{DISCLAIMER}

This report was prepared as an account of work sponsored by an agency of the United States Government. Neither the United States Government nor any agency thereof, nor any of their employees, make any warranty, express or implied, or assumes any legal liability or responsibility for the accuracy, completeness, or usefulness of any information, apparatus, product, or process disclosed, or represents that its use would not infringe privately owned rights. Reference herein to any specific commercial product, process, or service by trade name, trademark, manufacturer, or otherwise does not necessarily constitute or imply its endorsement, recommendation, or favoring by the United States Government or any agency thereof. The views and opinions of authors expressed herein do not necessarily state or reflect those of the United States Government or any agency thereof. 
ORNL/ER-389

Energy Systems Environmental Restoration Program

Completion Report for the Isolation and Remediation of Inactive Liquid Low-Level Radioactive Waste Tanks

7562, H-209, and T-30

at Oak Ridge National Laboratory,

Oak Ridge, Tennessee

Date Issued-December 1996

Prepared by

Advanced Sciences, Inc.

under subcontract 96B-99311C

Prepared for

the U.S. Department of Energy

Office of Environmental Management

under budget and reporting code EW 20

Environmental Management Activities at the

OAK RIDGE NATIONAL LABORATORY

Oak Ridge, Tennessee 37831

managed by

LOCKHEED MARTIN ENERGY SYSTEMS, INC.

for the

U.S. DEPARTMENT OF ENERGY

under contract DE-AC05-84OR21400 


\section{PREFACE}

This report provides documentation of the maintenance action completion for remediation of tanks 7562, H-209, and T-30 at Oak Ridge National Laboratory. This report will serve as the remediation completion documentation for the request to remove these tanks from the Federal Facility Agreement Appendix F listing.. This work was performed under Work Breakdown Structure 1.4.12.6.1.01.21, Activity Data Sheet 3301, "ORNL WAG 1 ER." 



\section{CONTENTS}

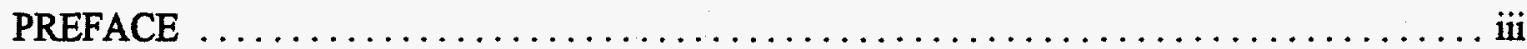

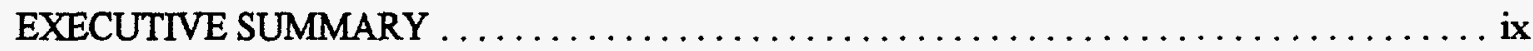

1. INTRODUCTION AND SITE DESCRIPTION $\ldots \ldots \ldots \ldots \ldots \ldots \ldots \ldots \ldots \ldots \ldots$

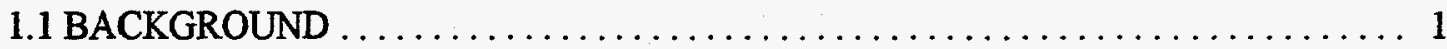

1.2 SITE DESCRIPTION $\ldots \ldots \ldots \ldots \ldots \ldots \ldots \ldots \ldots \ldots \ldots \ldots \ldots \ldots \ldots \ldots \ldots \ldots \ldots$

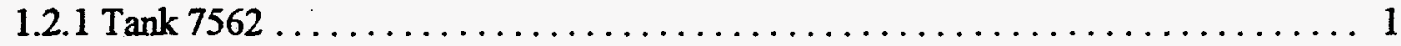

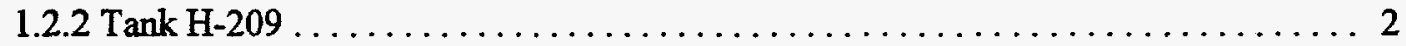

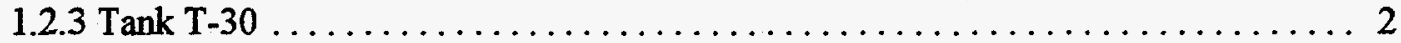

2. MAINTENANCE ACTION OBJECTIVES $\ldots \ldots \ldots \ldots \ldots \ldots \ldots \ldots \ldots \ldots \ldots \ldots \ldots \ldots \ldots$

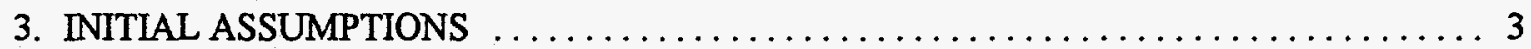

4. MAINTENANCE ACTION METHOD OF ACCOMPLISHMENT $\ldots \ldots \ldots \ldots \ldots \ldots \ldots$

5. MAINTENANCE ACTION FIELD ACTIVITIES $\ldots \ldots \ldots \ldots \ldots \ldots \ldots \ldots \ldots \ldots$

6. REMOVAL FROM FEDERAL FACILITY AGREEMENT LIST $\ldots \ldots \ldots \ldots \ldots \ldots \ldots \ldots$

7. RETENTION OF MAINTENANCE ACTION RECORDS $\ldots \ldots \ldots \ldots \ldots \ldots \ldots \ldots \ldots 4$

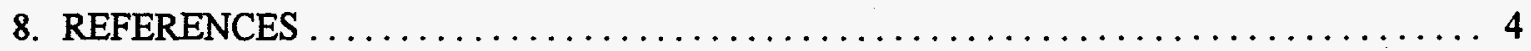





\section{TABLES}

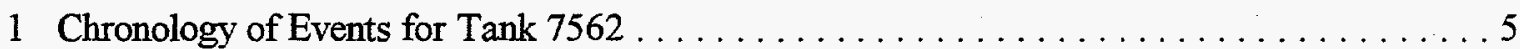

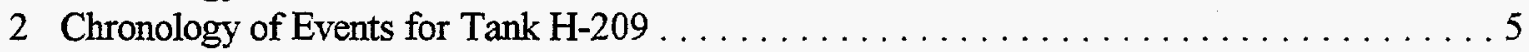

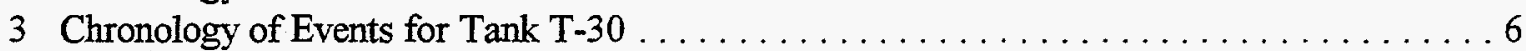

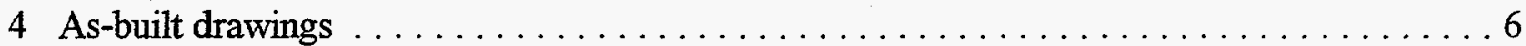




\section{EXECUTIVE SUMMARY}

The Federal Facility Agreement (FFA) among the U.S. Environmental Protection Agency (EPA), the Tennessee Department of Environment and Conservation (TDEC), and the U.S. Department of Energy (DOE) requires that all liquid low-level waste (LLLW) tanks at Oak Ridge National Laboratory (ORNL) that have been removed from service, designated in the FFA as Category D, to be remediated in accordance with Comprehensive Environmental Response, Compensation, and Liability Act (CERCLA) requirements.

A human health risk analysis was conducted on inactive tanks $7562, \mathrm{H}-209$ and T-30 to determine the method for remediating the tanks. Risk analysis results indicated that the health risk associated with these tanks were within or below the EPA range of concern of $1 \times 10^{-4}$ to $1 \times 10^{-6}$. On the basis of these results, and with regulator approval, it was determined that either no action or in-place stabilization of the tanks would satisfy risk-based remediation goals. Therefore, a decision was made and approved by DOE to remediate these tanks in-place as a maintenance action. Letters documenting these decisions were subsequently submitted to TDEC and EPA.

Tanks H-209 and T-30 were isolated from associated piping, electrical systems, and instrumentation and grouted in-place. Due to regulatory concerns over the location of tank 7562 relative to an area of subsurface soil contamination, tank 7562 was isolated from associated piping and instrumentation and left in-place empty.

Completion of these maintenance actions has met the intent of the FFA for remediation of inactive tanks H-209 and T-30. EPA and TDEC will be requested to approve a change to the FFA removing tanks H-209 and T-30 from the Appendix F list of inactive tanks. The request for removal of tank 7562 from Appendix $F$ will be submitted pending final disposition of the tank. Since the associated tank piping systems remain in-place, it will further be requested that these systems be included as individual sites in Appendix C of the FFA for future remedial consideration. 


\section{INTRODUCTION AND SITE DESCRIPTION}

\subsection{BACKGROUND}

The Federal Facility Agreement (FFA) among the U.S. Environmental Protection Agency (EPA), the Tennessee Department of Environment and Conservation (TDEC), and the U.S. Department of Energy (DOE) requires that all liquid low-level waste (LLLW) tanks at Oak Ridge National Laboratory (ORNL) that have been removed from service, designated in the FFA as Category $\mathrm{D}$, to be remediated in accordance with Comprehensive Environmental Response, Compensation, and Liability Act (CERCLA) requirements.

A human health risk analysis was performed on inactive tanks $7562, \mathrm{H}-209$, and T-30 using available characterization data associated with each tank. In each case, the results indicated risks associated with these tanks were within or below the EPA range of concern of $1 \times 10^{-4}$ to $1 \times 10^{-6}$. Based on these results, and with regulators approval, it was determined that either no action or in-place stabilization of the tanks would satisfy risk-based remediation goals. Therefore, a decision was made and approved by DOE to remediate these tanks in-place as a maintenance action rather than action under the CERCLA process. Letters documenting these decisions were approved by DOE and subsequently submitted to TDEC and EPA (Lingle, 1996).

\subsection{SITE DESCRIPTION}

The following subsections describe the tank sites as they were prior to maintenance action activities.

\subsubsection{Tank 7562}

Tank 7562 is a 12,000-gal stainless steel (SS) out-of-service tank located southeast of Building 7500 in Melton Valley. The tank was direct buried in 1957 under 4 to 6 feet of soil, and served as a LLLW storage tank for the Homogeneous Reactor Experiment (HRE). The tank also collected liquid from a decontamination pad located just west of the tank. Prior to remediation activities, the tank had a liquid inventory of $2,300 \mathrm{gal}$ which was monitored daily to ensure there were no inputs to or leaks from the tank.

Existing piping to the tank consists of a 2-in. diameter SS jet discharge line, 2-in. diameter SS spare line, and piping from the decontamination pad. Existing piping from the tank consists of a 1-in. diameter SS jet suction line and a 1.5-in. diameter SS overflow line routed to an inactive retention pond located south of the tank. A vertical 2-in. diameter SS pipe connected to the top of the tank is currently capped above grade. Two SS instrumentation lines are currently routed through one of the tank openings for high and low liquid level detection. Three SS sampling lines from Building 7502 are currently routed through another tank opening. A drywell is located near the east corner of the tank and is sampled monthly. 


\subsubsection{Tank H-209}

Tank $\mathrm{H}-209$ is a 2,500-gal carbon steel tank located southwest of Building 3517 , adjacent to White Oak Avenue, in the main ORNL area. The tank was installed in 1961 and held condensate and floor drainage from Building 3517. A 54-in. diameter corrugated metal pipe (CMP) manhole exists and houses equipment and instrumentation associated with the tank. Tank H-209 was emptied during September 1993 and showed no sign of inleakage. The tank liquid level was manually checked semiannually and remained empty prior to remediation activities.

Piping to the tank consists of a 3-in. diameter black steel (BS) line from the process sewer system. Radioactive-contaminated steam condensate was diverted from the process sewer system to tank $\mathrm{H}-209$ based on in-line monitoring near manhole 209. Based on analytical results of samples collected from tank $\mathrm{H}-209$, the liquid waste was either routed through a 2-in. diameter BS line back to the process sewer system through manhole 209 or routed through a 2-in. diameter BS line through cell \#15 to tank S523. A 2-in. diameter BS off-gas vent line from tank H-209 to cell \#15 maintained a negative pressure at the tank to eliminate potential release of airborne contamination. Prior to remediation activities, there was a negative pressure maintained in the pipe of approximately 6-in. $\mathrm{H}_{2} \mathrm{O}$.

Two SS instrumentation lines associated with a liquid level detection system mounted on the inside of the manhole are routed through two vertical SS pipes attached to the top of the tank. Two additional vertical SS pipes are also attached to the top of the tank on the opposite side of the main tank opening and house SS tubing.

\subsubsection{Tank T-30}

Tank T-30 is an 825-gal SS tank located at the south of Building 4507. The tank was installed in 1961 in an in-ground vault, and was removed from service in approximately 1980 . The tank stored radioactive materials for the Curium Recovery Facility in Building 4507. System piping consists of a 1-inch SS drain line from Building 4507; a 2-inch SS overflow line; and a 0.5-inch SS steam-jetdischarge line. A hole was cut into the tank for sampling in 1989, and a rubber stopper was subsequently placed into the hole. The tank was connected to the process off-gas system, and pit was kept at negative pressure by the cell ventilation system.

\section{MAINTENANCE ACTION OBJECTIVES}

The main objective of the maintenance actions were to safely and permanently remove tanks 7562 , H-209, and T-30 from service to eliminate the need for continued surveillance and maintenance (S\&M) of the tank systems. Meeting this objective involved isolation of each tank to prevent future inleakage or introduction of programmatic wastes, and securing each tank in-place by filling the tank with a controlled low-strength grout material. The grout consisted of a mixture of Type II cement, sand, FType fly ash, and water with a compressive strength of approximately $300 \mathrm{psi}$ and a permeability of $2 \times 10^{-5} \mathrm{~cm} / \mathrm{s}$. Closing the tanks in this way will prevent inadvertent accumulation of any free liquids in the tanks. The low compressive strength of the grout will pose a minimal hindrance to future remediation in the area, and the low permeability will effectively prevent the movement of free liquids into the tank. 


\section{INITIAL ASSUMPTIONS}

Early in the planning phases for these maintenance actions, initial assumptions were made concerning the status and configuration of each tank system. These assumptions were based on available system configuration information, sampling data, and engineering judgement.

Available sample data of tank contents was assumed to be adequate for the human health risk analysis and characterization of contents for removal and proper disposal. Based on this characterization data, it was determined that health risks associated with the tanks were within or below the EPA range of concern of $1 \times 10^{-4}$ to $1 \times 10^{-6}$.

The volume of fluid in the tanks was assumed based on available level measurement data from S\&M activities which indicated that tank 7562 had a volume of approximately 2,300 gal and that $H-$ 209 and T-30 were empty. The liquid in tank 7562 was removed as a S\&M activity prior to isolation the tank was rinsed several times, and liquids disposed of in the active LLLW system.

Available engineering drawings were assumed to accurately reflect tank and piping configurations that could not be visually verified before or during remediation activities. The engineering drawings listed in Section 7 of this report will be revised to reflect "as-built" conditions as a result of the maintenance actions.

\section{MAINTENANCE ACTION METHOD OF ACCOMPLISHMENT}

The maintenance action fieldwork for tanks 7562 and H-209 was performed in-house by the LMES Plant and Equipment Division. M-K Ferguson direct hire forces performed the maintenance activities for tank T-30. Waste Operations were utilized for pumping, rinsing, and disposal of the contents of tank 7562.. All work was conducted in accordance with the applicable Maintenance Action Work Plan (MAWP) and related Addendums (LMES, 1996); Waste Management Plan (WMP) (LMES, 1996), and Health and Safety Plan (LMES, 1996) prepared by LMES for remediation of tanks 7562, H-209 and T-30 except as follows:

- Because of regulatory concerns associated with the location of the tank 7562 in relation to potential contamination in the area, a decision was made by DOE and regulators not to fill the tank with grout during this maintenance action as specified in the MAWP. The tank was isolated from the system and left in-place empty.

- Because of the decision not to grout tank 7562, the excavated area above the tank remains open and was not backfilled as specified in the MAWP.

- Instrumentation lines associated with tank 7562 were cut and capped rather than crimped as specified in the MAWP.

- Tank H-209 and the associated manhole was grouted to approximately 6 to 12 inches below grade. Rather than grouting to the surface, as specified in the MAWP, the remainder of the manhole was filled with concrete to form a surface cap. 


\section{MAINTENANCE ACTION FIELD ACTIVITIES}

Tables 1,2, and 3 provide a chronology of maintenance action field activities related to remediating tanks 7562, H-209, and T-30. All maintenance activities were conducted in accordance with the MAWP except as indicated in Section 4 of this report.

As a result of these maintenance actions, tank 7562 is empty and isolated from associated piping and electrical systems. The soil area above tank 7562 remains excavated and open. Tanks H-209 and T-30 (including the vault) are isolated from associated piping, electrical systems, and instrumentation and filled with grout.

\section{REMOVAL FROM FEDERAL FACILITY AGREEMENT LIST}

Completion of this maintenance action has met the intent of the FFA for remediation of inactive tanks $\mathrm{H}-209$ and T-30. EPA and TDEC will be requested to approve a change to the FFA removing tank H-209 and T-30 from the Appendix F list of inactive tanks. The request for removal of tank 7562 from Appendix F will be submitted pending final disposition of the tank. Since the associated tank piping systems remain in-place, it will further be requested that these systems be included in Appendix $\mathrm{C}$ of the FFA for future remedial consideration.

\section{RETENTION OF MAINTENANCE ACTION RECORDS}

Photo and written documentation for this maintenance action will be retained under Project Record Number (PRN) X1995-0010 for tanks 7562, H-209, and T-30 as described in the Project Records Plan. The engineering drawings identified in Table 4 will be revised and maintained in the Engineering Drawing Information System to show the as-built status of the piping systems remaining at each tank site. Reference drawings for tank T-30 have already been revised and placed into the Engineering Drawing Information System.

\section{REFERENCES}

Letter from W. Nelson Lingle (LMES) to Doug McCoy (TDEC) and Victor Weeks (EPA), dtd July 9, 1996, Isolation and In-place Stabilization of Inactive Liquid Low Level Waste Tanks 7562 and H-209 at Oak Ridge National Laboratory (ORNL).

Maintenance Action Work Plan Addendum 1 and 2 of ORNL/ER-319 For Inactive LLLW Tanks 7562, H-209, and T-30 at Oak Ridge National Laboratory, Oak Ridge, Tennessee, dtd July 1996 and August 1996. 
Table 1. Chronology of events for Tank 7562

Date

$9 / 26 / 96$

$9 / 30 / 96$
Event

Plant and Equipment personnel mobilized to tank 7562 site and conducted radiological survey at top of tank. No contamination detected.

Began hot tapping, cutting, and capping piping connected to tank.

Completed capping all piping, demobilized from tank site, and returned area to same condition as prior to start of job.

Table 2. Chronology of events for Tank H-209

Date

$9 / 96$

\section{Event}

Plant and Equipment personnel mobilized to tank H-209 site.

Unhooked electrical wiring from within Building 3517 that was connected to instrumentation in the tank $\mathrm{H}-209$ manhole.

Conducted pre-job survey of tank H-209 manhole. No contamination was detected.

Electrical wiring pulled and dropped into tank $\mathrm{H}-209$ manhole.

Installed blind flange on piping and removed tank access cover.

Smears taken from the bottom of the tank cover and field checked. No contamination detected.

Cut up manhole cover with welding torch so it could be dropped into manhole.

Cut manhole pipe down to ground level and placed cut pieces into manhole.

Performed radiation and contamination survey of area around top of manhole. No contamination or radiation was detected.

Began grouting tank and manhole. Grouting ceased approximately 6 to 12 inches from ground surface due approximately 15 gal of water which floated to the surface of the grout. The water was frisked and read approximately $25,000 \mathrm{dpm}$ at a distance of about 2 inches from the water. The area around the manhole was surveyed and no contamination was detected outside of the manhole.

Dry concrete was placed into the manhole on top of the grout to absorb the standing water.

Performed survey on inside of manhole remaining to be filled. No contamination above normal background was detected.

Completed filling manhole with concrete to ground level forming a surface cap above the grout. site. 
Table 3. Chronology of events for Tank T-30

\begin{tabular}{cl}
\hline Date & \multicolumn{1}{c}{ Event } \\
\hline $8 / 96$ & - Mobilized to site and refurbished containment tent. \\
& - Removal lrad brick from vault. \\
& - Filled tank and vault with low permeable grout. \\
& - Removed and disposed of containment tent, miscellaneous equipment, and \\
$8 / 31 / 96$ & - minimal contaminated surface soil. \\
\hline
\end{tabular}

Table 4. Reference Drawings to be Revised

\begin{tabular}{|c|c|c|}
\hline Tank & Drawing number & Drawing title \\
\hline 7562 & E-24800 & $\begin{array}{l}\text { Outside Underground Waste \& Vent System } \\
\text { Piping }\end{array}$ \\
\hline 7562 & D-7587 & Evaporator Feed Tank Sheet \#1 \\
\hline 7562 & D-20769 & $\begin{array}{l}\text { Building } 7500 \text { Waste Lagoon and Storage } \\
\text { Tank }\end{array}$ \\
\hline 7562 & D-24816 & $\begin{array}{l}\text { Waste Evap. Instrument Piping Arrgt. \& } \\
\text { Details }\end{array}$ \\
\hline 7562 & Q-2529-78RO & Waste System Partial Plot Plan \& Sections \\
\hline 7562 & D-8309 & Waste \& Vent System Flow Sheet \\
\hline 7562 & D-7588 & Evaporator Feed Tank Details Sh. \#2 \\
\hline 7562 & D-24804 & Yard Piping Plan and Profile \\
\hline $\mathrm{H}-209$ & $D-42817$ & Electrical Plan, Elevations, \& Details \\
\hline $\mathrm{H}-209$ & D-46890 & Outside Underground Utilities \\
\hline $\mathrm{H}-209$ & D-39909 & $\begin{array}{l}\text { Chilled Water Return Changes Manipulator } \\
\text { Cell Face }\end{array}$ \\
\hline H-209 & D-39923 & $\begin{array}{l}\text { Condensate Tank \& Pump Piping - Plan \& } \\
\text { Section }\end{array}$ \\
\hline $\mathrm{H}-209$ & $D-45377$ & Condensate Tank Plans, Sections, and Details \\
\hline
\end{tabular}




\section{DISTRIBUTION}
1. P. W. Allen
2. L. V. Asplund
3. W. D. Brickeen
4. C. Clark
5. W. R. Clark
6. M. Clauberg
7. K. W. Cook
8. K. L. Deroos
9. J. T. Etheridge
10. D. L. Garrett
11. L. L. Kaiser
12. A. J. Kuhaida, Jr.
13-14. D. M. Matteo
15. J. A. Mayo
16. P. T. Owen
17. A. W. Saulsury
18. P. A. Schrandt
19. C. B. Scott
20. D. K. Stair
21. R. C. Stewart
22. M. L. Whitehead
23. F. H. Wright

24. ER Document Management Center-RC

25. J. H. Hawk, Advanced Sciences, Inc. 800 Oak Ridge Turnpike, Suite C-102, Oak Ridge, TN 37830-6927

26. B. Womble, MK-Ferguson, Bldg. 7505, MS 6401 